\title{
A modified stairstep apparatus for studies of allelopathy and other phytotoxic effects
}

\author{
J. V. LOVETT* and KARI JOKINEN
}

Department of Plant Husbandry, University of Helsinki, SF-00710 HELSINKI 71, Finland

\begin{abstract}
The characteristics and performance of a modified stairstep, nutrient solution recycling, apparatus are described.

An experiment in which the allelopathic potential of Agropyron repens was examined showed the apparatus to be reliable and accurate in operation. Allelopathic activity by $A$. repens was confirmed.

The apparatus is also suited to studies of phytochemicals produced in stubble retention reduced tillage systems, in green manuring and in cognate areas.
\end{abstract}

\section{Introduction}

The presence of phytochemicals and the roles which they play in agricultural systems are receiving increasing attention in the literature. Allelopathic phenomena (RICE 1974, 1979), whilst often difficult to distinguish among the interactions which take place between climate, soil, plants and other organisms (LOVETT 1982), occur commonly and demand better understanding than is presently the case. Phytotoxins are also of interest in reduced cultivation systems, especially where residues of crop and weed plants are retained

* Professor of Agricultural Science, University of Tasmania, G.P.O. Box 252C, Hobart, Tas. 7001, Australia. and decompose at rates determined by ambient climatic and edaphic conditions, by the activity of micro-organisms and by the method of cultivation (Lovert et al. 1982).

In the agricultural systems of Finland both allelochemicals and phytotoxins produced during the decomposition of plant residues in cropping systems seem likely to be of importance. Allelopathy has, for example, long been associated with Agropyron repens (L.) Beauv. (AAMisepp 1970) one of Finland's most important weed species. Living Agropyron may produce allelochemicals but greater phytotoxicity is usually associated with decomposition of the rhizomes (WELBANK 1963). LyNCH et al. (1980) suggest that short chain aliphatic acids are produced 
where decomposition is under anaerobic conditions. Such conditions also favour the production of similar substances, of proven phytotoxicity, from crop residues (LYNCH 1977).

Edaphic conditions favourable to the activity of facultatively anaerobic micro-organisms frequently occur in the heavy soils of Finland, particularly in autumn and early in spring. The possibility of phytotoxin production from $A$. repens, crop and weed residues is high at that time of year.

WiLSON and Rice (1968), BELL and KoEPPE (1972) and Walters and GiLmore (1976) have all applied the stairstep apparatus to studies of allelopathy. The technique seeks to distinguish between competition and allelopathy as components of interference (sensu HARPER 1977) by providing a nutrient flow through a closed system in which the interfering plants are physically separate but subject to the effects of phytochemicals released into the nutrient flow. In this paper we describe a modified stairstep apparatus which had wide application in studies of phytochemicals in agricultural systems.

Table 1. Comparison of allelopathy experiments using the stairstep apparatus.

\begin{tabular}{llll}
\hline Reference & WILSON and RICE (1968) & BELL and KOEPPE (1972) & WALTERS and GILMORE (1976) \\
Allelopathy of: & Helianthus anmuus L. with & Setaria faberii Herrm. with & Festuca arundinacea Screb. \\
& nine test species. & Zea mays L. & with Liquidamber styraciflua L. \\
\hline
\end{tabular}

\section{APPARATUS}

No. of lines

$\begin{array}{lll}5 & 4\end{array}$

No. of steps

.. not specified

4

4

No. of replicates

4

4

Method
Gravity flow and recycle $4 \mathrm{~h} /$ day. Nutrient solution replenished.
Gravity flow and recycle $4 \mathrm{~h} /$ day. Full strength Hoagland's Solution replenished. $\mathrm{pH}$ and conductivity of solution monitored.

Environment Greenhouse.

Greenhouse. $16 \mathrm{~h}$ photoperiod with supplementary light. Temperature: $21^{\circ} \mathrm{C}$ to $30^{\circ} \mathrm{C}$.

Medium

Quartz sand.

Quartz sand.

Live and dead Setaria material.

Test substances

Live $H$. annuus plants.

rial. Quantity of tissue related to field conditions.

\begin{tabular}{lll}
\hline $\begin{array}{l}\text { Parameters } \\
\text { monitored }\end{array}$ & Dry weight of test species. & $\begin{array}{l}\text { Fresh weight and dry weight } \\
\text { of test species. }\end{array}$
\end{tabular}

Four weeks.

Four weeks.

Height, dry weight and content of $\mathrm{N}, \mathrm{P}, \mathrm{K}, \mathrm{Ca}$ and $\mathrm{Mg}$ of test species.

\begin{tabular}{lll}
\hline Duration & Four weeks. & Four weeks. \\
\hline Observations & $\begin{array}{l}\text { Allelopathic effects on } \\
\text { five species, including } \\
\text { autotoxicity. }\end{array}$ & $\begin{array}{l}\text { Allelopathy by substances from } \\
\text { dearia material. }\end{array}$ \\
& &
\end{tabular}

\begin{tabular}{|c|c|c|}
\hline $\begin{array}{l}\text { Allelopathic } \\
\text { effect }\end{array}$ & Dry weight reduced. & $\begin{array}{l}\text { Reductions of height, fresh } \\
\text { weight and dry weight. }\end{array}$ \\
\hline
\end{tabular}
Sixteen weeks.

Allelopathy by substances primarily, from dead Festuca tissue.

Reductions in dry weight. Possible effects on chlorophyll, $\mathrm{N}$ and $\mathrm{P}$ content.

\begin{tabular}{|c|c|c|c|}
\hline $\begin{array}{l}\text { Primary } \\
\text { mechanism }\end{array}$ & No information. & No information. & $\begin{array}{l}\text { Possible effect on mineral } \\
\text { uptake. }\end{array}$ \\
\hline
\end{tabular}

Allelochemicals

Chlorogenic and isochlo- No information. rogenic acids suspected.
No information. 


\section{Material and Methods}

Development of the stairstep technique

MARTIN and RADEMACHER (1960) reported an improvement to a system devised by BORNER (1958) where in nutrient solution circulated through a series of pots in which plants of two species were planted, alternately. Various combinations of plants were tested by MARTIN and RADEMACHER (1960) who met "the most important technical requirement of the experiment", the prevention of depletion of nutrients in the system, by regular supplementation. There were some, apparently, allelopathic effects but no allelochemicals were identified.

The MARTin and RAdemacher apparatus does not appear to have followed the stairstep principle and we assume that this is the modification of the nutrient flow system to which WILsON and Rice (1968) refer. The salient features of their technique and those of Bell and KoEPPE (1972) and WALTERS and GiLmore (1976) are summarised in Table 1.

\section{The Viikki apparatus}

A modified stairstep apparatus was designed and built at the Department of Plant Husbandry, University of Helsinki. Each nutrient solution recycling unit within the system (Figure 1) comprised five steps. From a storage tank at the top of the system (step one) solution flowed, by gravity, through a sequence of pots to a collector tank (step five) from which it was automatically recycled by an electric pump (JoHnSON L 100 Bilge Pump.).

On step two of the apparatus was an incubation tray $(55 \times 37 \times 18 \mathrm{~cm})$ from which the circulating solution was channelled to test pots on each of the third and fourth steps. The test pots $(15 \mathrm{~cm}$ diameter, $14 \mathrm{~cm}$ height) were replicated four times and were individually supplied with solution from $3 \mathrm{~mm}$ internal diameter tubing inserted into collecting pipes below the second and third steps.

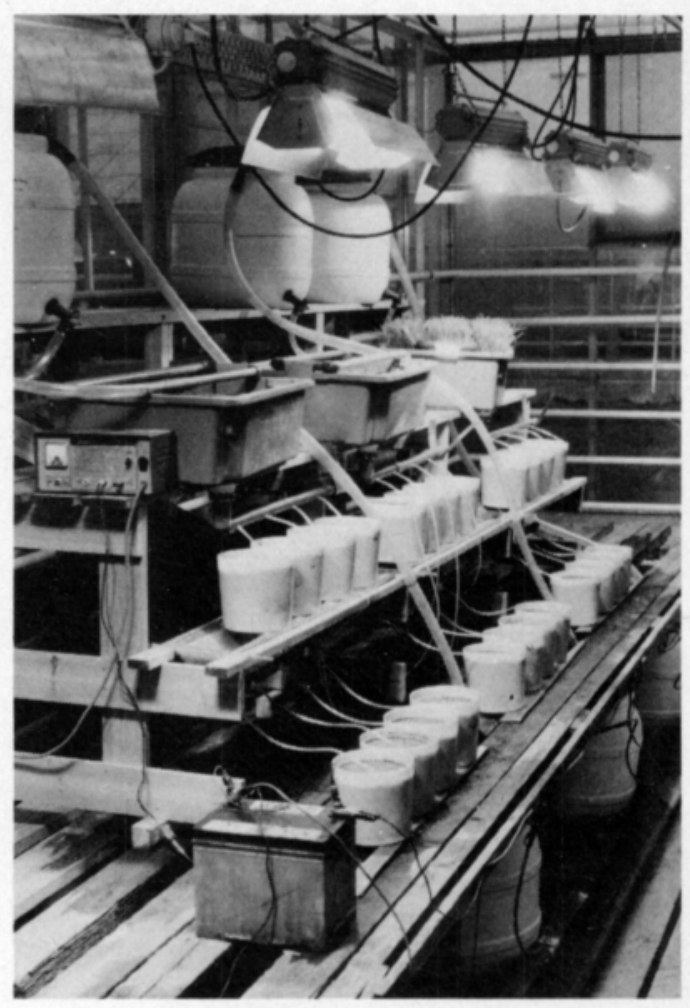

Fig. 1. The Viikki apparatus.

The incubation trays were lined with nylon mesh $(0.6 \mathrm{~mm}$ aperture) on which was placed a layer of gravel $(4.60-5.70 \mathrm{~mm}$ particle size, $15.4 \mathrm{~kg}$ dry weight). A second mesh, above the gravel base, was covered with sand $(0.50-1.20 \mathrm{~mm}$ particle size, $18.0 \mathrm{~kg}$ dry weight) and the entire system thoroughly flushed with tap water. Individual test pots were filled in similar fashion and contained $770 \mathrm{~g}$ gravel and $2.3 \mathrm{~kg}$ sand.

Three recycling units were set up in a greenhouse (mean temperature $21^{\circ} \mathrm{C} \pm$ $\left.2^{\circ} \mathrm{C}\right)$. A $16 \mathrm{~h}$ photoperiod was used, supplementary illumination being provided throughout by A/S Bergen RS 400, Lucalox U 400/ 40 lamps. The lamps did not affect temperature at the different step levels but there was a drop in light intensity from $370 \mu \mathrm{Em}^{-2} \mathrm{~s}^{-1}$ to $200 \mu \mathrm{Em}^{-2} \mathrm{~s}^{-1}$ between the third and fourth steps ('Top' and 'Base' sets of test pots). 
The volume of $3010.2 \%$ 'Kemira Nestemäinen Y-lannos' complete nutrient solution (pH 7.2, N 140 mg/l, P 20 mg/l, K 120 mg/l, $\mathrm{Na} 16 \mathrm{mg} / \mathrm{l}, \mathrm{S} 14 \mathrm{mg} / \mathrm{l}$, B $54 \mu \mathrm{g} / \mathrm{l}$, Mo $12 \mu \mathrm{g} /$ 1, Fe $18 \mu \mathrm{g} / \mathrm{l}$, Mn $6 \mu \mathrm{g} / \mathrm{l}$, Ca $4 \mu \mathrm{g} / \mathrm{l}, \mathrm{Mg}$ $1.2 \mu \mathrm{g} / \mathrm{l}, \mathrm{Cu} 0.6 \mu \mathrm{g} / \mathrm{l}, \mathrm{Zn} 0.6 \mu \mathrm{g} / \mathrm{l}$, Co $0.6 \mu \mathrm{g} / \mathrm{l})$, made up with tap water, in the storage tank was replenished on alternate days. Flow rate of solution through the system was adjusted to $23 \mathrm{l} / \mathrm{h}$ and the solution was cycled for $6 \mathrm{~h}$ /day.

\section{Application of the apparatus}

The modified stairstep apparatus was used in an assessment of the allelopathic potential of Agropyron repens (L.) Beauv. (couchgrass).

Couchgrass was freshly harvested from the field at Viikki. Top growth was cut back to $3 \mathrm{~cm}$ height and the rhizomes thoroughly washed in tap water. Into the incubation tray of one unit was placed $1.2 \mathrm{~kg}$ (fresh weight) rhizomes with top growth, an amount which corresponded to that recovered from an equivalent volume of soil in a badly contaminated field. A similar weight of material was finely chopped and incorporated into the sand at $10 \mathrm{~cm}$ depth in a second incubation tray, where it decayed. The third, control, tray received only nutrient solution.

Each experiment in a series ran for one week. The height couchgrass foliage in the 'Live' treatment was maintained at, or near, $10 \mathrm{~cm}$ height. Any shoots appearing from the 'Decay' treatment were removed.

The test species was Hordeum vulgare L. (barley) cv. Kustaa. Into each test pot were sown 14 graded seeds ( 2.5 to $2.8 \mathrm{~mm}$ diameter). Emergence was monitored from its commencement on Day 3 of each experimental run. On day 7 the plants were carefully washed from the test pots. Root loss was minimal. The height of the first leaf and length of the longest seminal root were determined. The plants were divided into leaf, seed and root portions which were dried at $100^{\circ} \mathrm{C}$ for $48 \mathrm{~h}$ and weighed.
It was possible to thoroughly clean and refill the test pots with fresh gravel and sand; to clean the tubes in the recycling system, and to commence the next run on the day of harvest.

Data were analysed using a statistical package available through the Helsinki School of Economics Computer Centre. Analysis of Variance was applied to untransformed data. Variability was small and there was, for example, no necessity to re-randomise pots within steps as the flow rate of nutrient solution and the ambient conditions were uniform.

\section{Results and Discussion}

Previous examples of the use of the stairstep apparatus (Table 1) provide little information on performance. The Viikki apparatus proved simple and reliable in operation. $\mathrm{pH}$ was monitored daily and did not vary from the initial value of 7.2. The $\mathrm{NO}_{3}$ concentration of the solution in the recycling units varied from 133 to $146 \mathrm{mg} / 1$ as compared with $151 \mathrm{mg} / \mathrm{l}$ in unused solution. Germination tests, using solution pipetted from the recycling units whilst in operation, indicated no contamination by pathogens which might affect growth of the test species. Some algal growth was, however, observed.

Developments from earlier versions (Table 1) include the provision of large incubation trays, as compared with pots of $12 \mathrm{~cm}$ diameter (BELL and KoEPPE 1972) or $19 \mathrm{~cm} \mathrm{dia-}$ meter (WALTERS and GILMORE 1976). The relative homogeneity of phytotoxin-producing material, the amount of which was related to field conditions, and the possibility of maintaining the material for indefinite periods in large containers are significant advantages. They permit, for example, monitoring of phytotoxin production over time, and sequential harvesting as compared with single harvests in earlier experiments, Table 1.

A difference in light intensity between steps was observed by WALTERS and GILMORE (1976). This occurred also in our experiments 
but there was no difference in ambient temperature. Statistically significant effects of position were recorded for shoot height at harvest (Table 2) and for shoot and total dry weight.

Whilst data are here presented, primarily, in validation of the technique, they confirm the allelopathic potential of $A$. repens. Thus the presence of decaying or live couchgrass material affected the test species from the commencement of growth and was evidenced in morphological and physiological characteristics at harvest, Tables 3 and 4 . The apparently progressive decline in total dry weight (Table 4) is a consequence of delayed sowing in Run 2 whilst the system was cleaned and of the removal of the second leaf of all plants in Run 3 for the determination of chlorophyll content.

The primary causes of the effects and the possibility that different chemicals are produced by live (GABOR and VEATCH 1981) and decaying (LYNCH 1977) material of $A$. repens are the subject of further investigations.

In earlier experiments, alternate pots of phytotoxin-producing and test species have been employed (Börner 1958; MARTIN and RADEMACHER 1960; WILSON and RICE 1968; Bell and KoepPe 1972; MARTIN and Gilmore 1976). Only WILSON and RICE (1968) used species which demonstrated that autotoxicity could occur in a stairstep apparatus. The type and amount of phytochemicals produced by autotoxified plants may, of course, differ from that of non-toxified material.

Table 2. Effect of position of test pots on height or barley shoots (means of four replicates).

\begin{tabular}{lccc}
\hline Position & \multicolumn{3}{c}{ Mean shoot height $(\mathrm{cm})$} \\
\cline { 2 - 4 } & Run 1 & Run 2 & Run 3 \\
\hline Top & 18.58 & 19.37 & 18.05 \\
Base & 17.58 & 18.78 & 17.15 \\
\hline p & $<0.001$ & $<0.01$ & $<0.001$ \\
LSD (t) p $<0.05$ & 0.52 & 0.34 & 0.52 \\
& 0.71 & 0.47 & 0.71 \\
Coefficient of & & & \\
Variation $(\%)$ & 3.36 & 2.08 & 3.43 \\
\hline
\end{tabular}

Table 3. Effect of couchgrass on length of barley roots (means of four replicates).

\begin{tabular}{lrcc}
\hline Treatment & \multicolumn{3}{c}{ Mean root length (cm) } \\
\cline { 2 - 4 } & Run 1 & Run 2 & Run 3 \\
\hline Control & 11.11 & 13.91 & 10.75 \\
Decay & 9.97 & 12.48 & 11.25 \\
Live & 9.71 & 11.25 & 12.42 \\
\hline p & 0.05 & $<0.001$ & $<0.001$ \\
LSD (t) p $<0.05$ & 1.01 & 0.84 & 0.72 \\
$\quad$ p $<0.01$ & 1.38 & 1.15 & 0.98 \\
Coefficient of & & & \\
Variation $(\%)$ & 9.32 & 6.35 & 5.95 \\
\hline
\end{tabular}

Table 4. Effect of couchgrass on total dry weight of barley (means of four replicates).

\begin{tabular}{llrr}
\hline Treatment & \multicolumn{3}{c}{ Mean total dry weight $(\mathrm{mg})$} \\
\cline { 2 - 4 } & Run 1 & Run 2 & Run 3 \\
\hline Control & 39.69 & 32.78 & 29.36 \\
Decay & 39.94 & 30.86 & 29.02 \\
Live & 39.34 & 30.64 & 27.38 \\
\hline p & N.S. & $<0.05$ & $<0.01$ \\
LSD $(\mathrm{t}) \mathrm{p}<0.05$ & - & 1.66 & 1.21 \\
$\quad \mathrm{p}<0.01$ & - & 2.27 & 1.66 \\
Coefficient of & & & \\
Variation $(\%)$ & 5.58 & 5.02 & 4.02 \\
\hline
\end{tabular}

The Viikki apparatus does not exclude the possibility of autotoxicity, however, output from the incubation trays is filtered through two series of test pots before recycling, reducing the possibility of its occurring. This proposition is supported by the interaction between position and treatments (Figure 2),

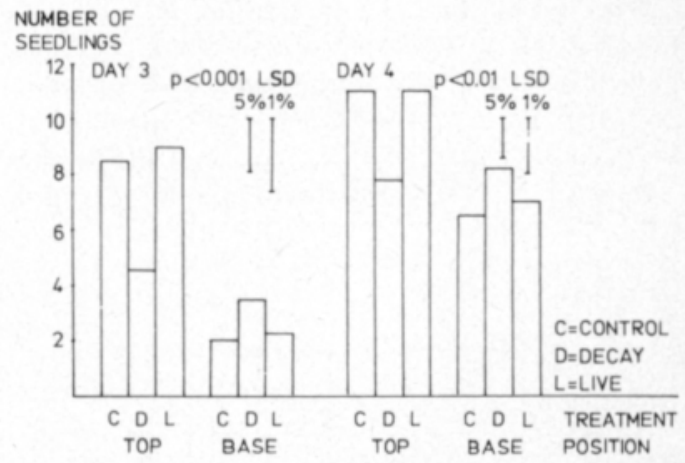

Fig. 2. Position by treatment interaction in emergence of seedlings. Run 2 . 
in which an apparent inhibition by decaying couchgrass at the top position becomes a stimulation at the base. This effect implies a reduced concentration of phytochemicals, and the type of response noted by LOVETT (1982).

More detailed information on allelopathy by $A$. repens as manifest in the stairstep apparatus will be published elsewhere. The apparatus is equally suited to studies of phytochemical production during decomposition of crop and weed residues in reduced cultivation systems or where green manuring is practised.

Given that the growing season in Finland

\section{References}

AAmisepp, A. 1970. Influence of plant extracts on growth of seedlings. Lantbr.högsk. Ann. 36: 153178.

Bell, D. T. and Koeppe, D. E. 1972. Noncompetitive effects of giant foxtail on the growth of corn. Agron. J. $64: 321-325$.

BÖRNER, H. 1958. Experimentelle Untersuchungen zum Problem der gegenseitigen Beeinglussung von Kulturpflanzen und Unkräutern. Biol. Z.bl. 77: $310-328$.

GABOR, W. E. and VEATCH, C. 1981. Isolation of a phytotoxin from quackgrass (Agropyron repens) rhizomes. Weed Sci. 29: 155-159.

Harper, J. L. 1977. Population Biology of Plants. Academic Press. London. 892 p.

LOVETT, J. V. 1982. Allelopathy and self-defence in plants. Austr. Weeds 2: 33-36.

Lovett, J. V., Hoult, E. H., Jessop, R. S. and Purvis, Christine E. 1982. Implications of stubble retention. Proc. Second Austr. Agron. Conf. p. 101-115.

Lynch, J. M. 1977. Phytotoxicity of acetic acid produced in the anaerobic decomposition of wheat straw. J. Appl. Bact. 42: 81-87.

Lynch, J. M., Hall, K. C., Anderson, H. A. and Hepburn, A. 1980. Organic acids from the anaerobic is short it is desirable to minimise the stresses to which crop and pasture plants are subject, particularly during early growth and development. Understanding phytochemical effects is of potential significance in reducing stress and improving productivity in many agricultural systems.

Acknowledgements: The Finnish Academy of Sciences generously funded the visit, organised by Professor Eero Varis, which made possible the participation of one of us (J. V. L.) in this programme. The equipment was skilfully constructed by kenttämestari Reino Hakala.

Our thanks for these several sources of support are gratefully recorded.

decomposition of Agropyron repens rhizomes. Phytochemistry 19: 1846-1847.

Martin, P. and Rademacher, B. 1960. Studies on the mutual influences of weeds and crops. In $n$ The Biology of Weeds» ed. J. L. Harper, Blackwell, Oxford. p. $143-152$.

RicE, E. L. 1974. Allelopathy. Academic Press, New York. $353 \mathrm{p}$.

RicE, E. L. 1979. Allelopathy - an update. Bot. Rev. 45: $15-109$.

ToAl, T. V. and Linscott, D. L. 1979. Phytotoxic effects of decaying quackrass (Agropyron repens) residues. Weed Sci. 27: 595-598.

W ALters, D. T. and GILmore, A. R. 1976. Allelopathic effects on the growth of sweetgum. J. Chem. Ecol. 2: 469-479.

Welbank, P. J. 1963. Toxin production during decay of Agropyron repens (Couch Grass) and other species. Weed Res. 3: 205-214.

WILsON, R. E. and RicE, E. L. 1968. Allelopathy as expressed by Helianthus annuus and its role in old-field succession. Bull. Torrey Bot. Club 95: $432-448$.

Ms received December 1, 1984 


\section{SELOSTUS}

\section{Muunneltu uuttojärjestelmä allelopaattisten}

ja muiden fytotoksisten vaikutusten

tutkimiseksi

\section{J. V. Lovett ja Kari Jokinen}

Helsingin yliopisto kasvinviljelytieteen laitos, 00710 Helsinki 71

Tässă työssă kuvataan kiertảvăăn liuosjărjestelmaaăn perustuvan laitteiston ominaisuuksia ja käyttöä. Koe, jossa tutkittiin juolavehnän mahdollista allelopaattista vaikutusta, osoitti, että kehitetty laitteisto on kăytössä luotettava ja tarkka. Koe vahvisti myös käsityksiä, joiden mukaan juolavehnă on allelopaattisten yhdisteiden tuottaja.
Laite on sovellettavissa myös tutkimukseen, jossa selvitetăăn eri viljelymenetelmissä mahdollisesti esiintyvien fytokemikaalien vaikutusta kasvien alkukehitykseen. 